\title{
The Macroeconomic Contribution of Agricultural Economics to National Growth and Development
}

\author{
Odeigah Dennis Chukwueloke \\ National Biotechnology Development Agency, Umaru Musa Yar'Adua Express Way, Abuja, Nigeria \\ Email address: \\ thinkwell07@yahoo.com

\section{To cite this article:} \\ Odeigah Dennis Chukwueloke. The Macroeconomic Contribution of Agricultural Economics to National Growth and Development. \\ International Journal of Agricultural Economics. Vol. 4, No. 6, 2019, pp. 296-300. doi: 10.11648/j.ijae.20190406.17
}

Received: February 23, 2019; Accepted: April 8, 2019; Published: December 26, 2019

\begin{abstract}
This study was undertaken to investigate the macroeconomics of agricultural economics using secondary data collected from different sources to appraise results in the course of the research. The analysis was to determine the macroeconomic contribution of agricultural economics to national growth and development. The survey revealed that agricultural economics helps to enhance investment, employment, trade, foreign exchange earnings, government revenue, food security, technological innovation, economic growth and development. In addition, in all contributions to the gross domestic product (GDP), agriculture is most vital, because no work or thought can be exercised without the release of energy which comes from food. The following recommendations are proffered to increase the influence of agricultural economics on the macroeconomics of a national economy: the monetary policy rate (MPR) or discount rate (DR) should be reduced to $0-2 \%$ to enhance agricultural production, tax revenues, exports, employment, food security, technological innovation, and the GDP.
\end{abstract}

Keywords: Macroeconomics, Agricultural Economics, Investment, Food Security, Economic Growth and Development

\section{Introduction}

Agricultural economics is the scientific study of how to effectively and efficiently utilize and allocate scarce agricultural resources in order to satisfy insatiable human and animal needs and wants [1]. Macroeconomics is the scientific study of economics at the aggregate level; it's the scientific study of the overall performance of the economy [4].

Agricultural economics is a branch of economics, which is majorly divided into microeconomics and macroeconomics. The predilection of this article is to discover how agricultural economics contributes to macroeconomics towards national growth and development via: investment; employment; trade, foreign exchange earnings and government revenue; food security; technological innovation; and economic growth and development.

\section{Objective}

The objective of this article is to determine the macroeconomic contribution of agricultural economics to national growth and development.

\section{Investment}

Agricultural economists are policy makers in the agricultural field. Meaning, they come with policies which will expand agricultural productivity and farm incomes. The surplus output and farm incomes encourage subsequent investments by the agricultural investors (farmers and speculators) into the financial and real investment sectors of the economy. This totality of investments: agriculture, financial, and real, eventually expand government revenue via taxes, and the gross domestic product (GDP). However, the aforementioned can only be achieved when the monetary policy rate (MPR) or discount rate (DR) is reduced to $0-2 \%$ to enhance agricultural production, tax revenues, exports, employment, food security, technological innovation, and the GDP.

\section{Employment}

Implementation of easy-money and free enterprise policies expand employment in the agricultural sector on a grand scale, thus healing to a great extent the 
unemployment syndrome of governments worldwide. They also encourage to a very great extent freedom of ideas, which exude a very vibrant and resilient society, characteristic of sustainable leadership, and devoid of authoritarian, parochial leadership.

Investors in nations with high unemployment rates have been for a very long time finding it very difficult to access funds for agricultural investments to expand agricultural incomes and farm production. With the implementation of easy-money and free enterprise policies, while ensuring adequate inflation-management measures, employment in the agricultural sector will increase in nations with unemployment constraints.

\section{Trade, Foreign Exchange Earnings and Government Revenue}

Trade with foreign nations increase, on the agricultural aspect, when agricultural output increases due to the influence of agricultural economics, as a result of the implementation of easy-money and free enterprise policies. Foreign exchange earnings follow suit in increment, along with government revenues via taxes on agricultural products: crops and animals.

\section{Food Security}

One of Governments' challenges for a protracted period has always been the inability to achieve food security. This has been as a result of their tight-money-policies and their excessive social projects, which are inimical to prevailing free enterprise management style, prevalent in international communities of developed natures.

When governments implement an easy-money-policy, complemented with a free enterprise policy, agricultural productivity would increase, with subsequent attainment of food security.

\section{Technological Innovation}

Being encapsulated by a policy formulation spirit to achieve macroeconomic stability as regards the agricultural clime, agricultural economics immensely contributes towards the innovation of agricultural technologies, for example, improved seed varieties, greenhouse farming, farm machinery, etc.

It is the sole function of agricultural economics to continually seek for new ideas on how to expand agricultural productivity and farm incomes, with commensurate extension, through extension science, of improved agricultural technologies to areas low in productivity and incomes to spring up development in these areas.

\section{Economic Growth and Development}

Economic growth simply refers to the successive expansion of the GDP, while development refers to the effective and efficient establishment of social infrastructures and economic policies within the socioeconomic system, which gives rise to the successive expansion of the GDP. Insubstantial development leads to low GDPs.

The GDP is arrived at through a simple mathematical formula: $\mathrm{GDP}=\mathrm{C}+\mathrm{G}+\mathrm{I}+\mathrm{X}$ (Where, $\mathrm{C}=$ Consumer purchases, $\mathrm{G}=$ Government purchases, $\mathrm{I}=$ Domestic investment, $\mathrm{X}=$ Net exports). Agricultural economics is reflected in the four factors of the GDP. As captured under technological innovation, the implementation of favourable agricultural policies on the agricultural enterprise expands consumer agricultural purchases, government agricultural purchases, domestic agricultural investment and agricultural net exports, which all summatively and successively expand the annual GDP, while enhancing development in the process.

\section{Conclusion}

This study deals with the macroeconomic contribution of agricultural economics to national growth and development. The issues discussed in this article were based on the review of relevant literature.

The study revealed that agricultural economics significantly contributes to the macroeconomic status of nations, like Nigeria, via investment; employment; trade, foreign exchange earnings and government revenue; food security; technological innovation; and economic growth and development.

In addition, nations like the United States of America, China, Falkland Islands, etc. have benefitted from the role of agricultural economics in their economies towards achieving macroeconomic stability in their nations and economies. Their GDPs have appreciated, government revenues have risen to magnificent levels and export earnings have seen positive turnarounds.

Every nation works to expand her revenue base to meet the teeming demands of her people or populations, the macroeconomics of agricultural economics expands the revenue base of government significantly via many resources, based on the fact that one cannot work or think without eating.

Investing in agricultural economics, which is the foundation of economies world over, also significantly causes the macroeconomic social and economic indicators to appreciate.

From the findings of this study, the following conclusion can be drawn that agricultural economics significantly contributes to the macroeconomics of a nation towards national growth and development.

The following recommendation is made:

The Monetary Policy Rate (MPR) or discount rate (DR) should be reduced to $0-2 \%$ to enhance agricultural production, tax revenues, exports, employment, food security, technological innovation, and the GDP. 


\section{References}

[1] Barkley, A. and P. W. Barkley (2013). Principles of Agricultural Economics. Routledge.

[4] Samuelson, P. A. and W. D. Nordhaus (1998). Economics, Sixteenth edition. The McGraw-Hill Companies, Inc.

[5] The Economist (2013). vol. 408, no. 8852.

[6] The Economist (2014). vol. 413, no. 8916.

[2] Cramer, G. L. and C. W. Jensen (1994). Agricultural Economics and Agribusiness Study Guide, Sixth edition. Wiley.

[3] Debertin, D. L. (2012). Agricultural Production Economics (the Art of Production Theory). Createspace Independent Pub.

[7] The Economist (2016). vol. 420, no. 8999.

[8] Federal Ministry of Finance (2000). Quarterly Performance Report on the Economy: April - June. Abuja, Nigeria.

[9] Federal Ministry of Finance (2000). Quarterly Performance Report on the Economy: July - September. Abuja, Nigeria. 